\title{
CONTRIBUTION OF RADIOCARBON DATING TO THE CHRONOLOGY OF ENEOLITHIC IN CAMPANIA (ITALY)
}

\author{
I. PASSARIELLO ${ }^{1}$, P. TALAMO ${ }^{2}$, A. D’ONOFRIO ${ }^{1}$, P. BARTA $^{3}$, C. LUBRITTO $^{1}$ and F. TERRASI ${ }^{1}$ \\ ${ }^{l}$ CIRCE, Environmental Sciences Department, Second University of Naples, and INNOVA, Caserta, Italy \\ ${ }^{2}$ Soprintendenza per i Beni Archeologici di Avellino e Salerno, Italy \\ ${ }^{3}$ Dendrochronological Laboratory Bratislava and Department of Archaeology, Faculty of Philosophy, Comenius University, Slovakia
}

Received 3 July 2007

Accepted 1 March 2010

\begin{abstract}
The paper presents new and important ${ }^{14} \mathrm{C}$ data from eight Eneolithic sites in Campania measured at the Centre for Isotopic Research of Cultural and Environmental Heritage (CIRCE) AMS laboratory in Caserta (Italy). Twenty-four ${ }^{14} \mathrm{C}$ determinations on bone and charcoal are used here for chronological reconstruction of human habitation and dating of some volcanic eruptions affecting the settlement activity. Our research has shed new light on absolute chronology of the whole Campanian Eneolithic, a period of profound cultural transformations triggered by introduction and use of metals, in particular copper.
\end{abstract}

Keywords: Eneolithic, chronology, radiocarbon dating, archaeological cultures, eruptions

\section{INTRODUCTION}

Campania is a region in southern Italy (regional capital Naples) with abundant evidence of pre- and protohistoric habitation. Its geomorphology is characterized by volcanic complexes like Somma-Vesuvius and Phlegrean Fields, whose eruptions acted as agents of landscape formation with a positive impact on soil fertility. Excavations in Campania have yielded many sites buried below large amounts of stratified pyroclastic deposits of a number of Phlegrean and Vesuvius eruptions. While on the one hand the volcanic activity favoured farming and development of human habitation, on the other it caused catastrophic destructions.

The Metal age in Europe started with the Copper Age, which is in Italy more usually termed Eneolithic (from Latin aes, copper). The term Eneolithic (ca 4000-2300 cal BC) emphasizes introduction of first metal objects and their use along with stone implements. The period is characterized also by other technological innovations, from which ensued a better land exploitation and demographic increase. In Campania, the Eneolithic period is bracketed between the Neolithic Diana culture and the earliest Bronze Age. There are two principal Eneolithic

Corresponding author: I. Passariello

e-mail: Isabella.passariello@unina2.it

ISSN 1897-1695 (online), 1733-8387 (print) (C) 2010 GADAM Centre, Institute of Physics, Silesian University of Technology.

All rights reserved. cultures in Campania - Gaudo and Laterza. The earlier one, Gaudo culture (from Gaudo cemetery, few kilometres from Paestum, Salerno), represents the Middle Eneolithic. The Gaudo culture was spread also in Calabria, Basilicata, Molise, and southern Lazio. The later one, Laterza culture (from Laterza cemetery, near Bari), represents the Late Eneolithic. Apart form Campania, Laterza culture was present also in Lazio, Puglia, and Basilicata.

Recent investigations in Campanian provinces Avellino (AV), Naples (NA), Caserta (CE), and Salerno (SA) have allowed archaeologists to identify new sites and cultures, which better characterize regional Eneolithic. Above all, the recognition of a new culture, named Taurasi (after a cemetery excavated in Taurasi near AV) that is attributable to the Early Eneolithic must be seen as a significant achievement. Other cultures, albeit not that clearly distinguishable by now, have been defined as well; one of the oldest, Macchia a Mare-Spatarella culture, is referable to the transition from the Late Neolithic to Early Eneolithic. The recent excavations have also investigated close relationship between several Eneolithic sites and the coeval volcanic eruptions. In this respect the Phlegrean eruptions Agnano 3 and Paleoastroni 2, which covered a lot of Eneolithic settlements, represent important chronostratigraphic markers (Talamo, 2008a and 2008b). 
Accordingly, the current state of things presents favourable conditions for a reconstruction of complete chronological and cultural sequence of Eneolithic in Campania. Albeit the most of recent excavations have not been brought to the public in full, the published information are sufficient to describe cultural and stratigraphic position of the finds. However, ${ }^{14} \mathrm{C}$ dates until recently available have been very few and from various sites and contexts (S. Maria dei Bossi: Albore Livadie and Gangemi, 1988; S. Antonio di Buccino: Holloway, 1973; Gaudo: Bailo Modesti and Salerno, 1998).

Having been spurred by the recent important discoveries, the aim of our work is to produce new absolute chronological evidence for Eneolithic in Campania and several volcanic eruptions with impact on excavated settlements below presented. In fact, the extended ${ }^{14} \mathrm{C}$ data set - which we bring for the first time here - worked by the Bayesian tools is intended to make a fresh contribution to the research of cultural-chronological development of the period. Further, it is to enhance the dating resolution of some eruptions, which influenced human habitation in the region.

\section{MATERIALS AND METHODS}

In order to investigate absolute chronological questions, charred wood, seeds, and bone samples were collected from different archaeological sites dated to the Early, Middle and Late Eneolithic.

All the samples were prepared for AMS ${ }^{14} \mathrm{C}$ dating at the CIRCE laboratory in Caserta (Campania, Italy). They were chemically treated to isolate the carbon fraction and eliminate contaminants. For charcoal and seeds, the AAA (Acid-Alkali-Acid) protocol was used (Mook and Streurman, 1983). Bones were chemically treated in the CIRCE radiocarbon sample preparation laboratory using collagen extraction protocol (Longin, 1971; Stafford et al, 1987) modified with the addition of basic treatment $(\mathrm{NaOH})$ (Arslanov and Svezhentsev, 1993; Piotrowska and Goslar, 2002) in order to eliminate humic contaminants. For comparison, five samples were prepared in the Research Laboratory for Archaeology and the History of Art in Oxford using routine collagen extraction procedures, with an additional ultrafiltration step to purify the bone gelatine (Brown et al, 1988; Bronk Ramsey et al, 2004).

After the chemical pre-treatment, samples together with copper oxide grains were introduced in quartz tubes, which were evacuated and sealed and then combusted in muffle furnace at $920^{\circ} \mathrm{C}$ for $6 \mathrm{hrs}$. After combustion, the produced $\mathrm{CO}_{2}$ was purified in a cryogenic line and reduced to graphite either by the Bosch reaction using Fe as catalysts in a multisample graphitization line (Passariello et al., 2007) or by a Zinc reducer using Fe as catalysts (Marzaioli et al., 2008). Then, graphite targets were measured by the CIRCE AMS system in Caserta (Terrasi et al., 2007; Terrasi et al., 2008). Note that, in this work, all radiocarbon dates are shown by our Lab index (CIRCE-DSA/DSH), because the measurements were done by the CIRCE AMS system. The dates from the literature, shown in the figures, are accompanied by references. The obtained radiocarbon ages were calibrated using OxCal program (Bronk Ramsey, 2001), considering INTCAL04, the calibration curve acceptable for the calibration of all analysed samples (Reimer et al., 2004).

\section{RESULTS AND DISCUSSION}

This study is the first work in Campania, which investigates a whole period of Eneolithic by the series of ${ }^{14} \mathrm{C}$ dates analyzed by means of Bayesian chronological models. The ${ }^{14} \mathrm{C}$ dates in models are organized according to proven or postulated real-time relations between individual determinations. The real-time relations are derived from physical-stratigraphical observations between ${ }^{14} \mathrm{C}$ samples and from outcomes of complex archaeological relative-chronological investigations.

Results are presented and discussed following the archaeological relative chronology of sites dated to the Early, Middle, and Late Eneolithic. The subdivision in three periods was made according to the cultural sequence characterized by archaeological artifacts (mainly potteries) and, afterwards, confirmed by absolute dates obtained in this work. All the sites with ascribed archaeological period and number of dated samples are listed in Table 1.

\section{Chronological investigations of Early Eneolithic}

\section{- San Martino - Taurasi (Avellino)}

The most important result of 1993-1996 archaeological excavations of San Martino, a site on the Taurasi hill, is a discovery of unique Early Eneolithic evidence until then without comparisons elsewhere. Apart from Eneolithic, the site was occupied in the Early Neolithic ("Ceramica Impressa" culture settlement), the Late Roman period and the Early Middle Ages. It also has yielded traces of rural settlements on soil above the "Avellino" pumices (1935-1880 BC; Passariello et al., 2009).

The Early Eneolithic evidence unearthed at San Martino - Taurasi represents five structures of special purpose. They were of trapezoidal or apsed shape with low dry-stone walls or only postholes. Around these structures and on or below associated walking horizon a lot of cremation tombs appeared. The construction elements of these structures together with a number of pottery and objects indirectly connected to the tombs reinforce the idea that the five buildings were related to the cult of the dead, served as tomb shelters and not as dwellings.

Table 1. Investigated sites with their archaeological period and number of samples dated.

\begin{tabular}{llc}
\hline Sites & Historic period & $\begin{array}{c}\text { Sample } \\
\text { number }\end{array}$ \\
\hline S.Martino (Taurasi, Avellino) & Early Eneolithic & 4 \\
\hline S.Maria dei Bossi (Casalbore, & Early Eneolithic & 5 \\
Avellino) & Middle Eneolithic & 1 \\
\hline Piano di Sorrento (Napoli) & Middle Eneolithic & 5 \\
\hline Caivano (Napoli) & Middle Eneolithic & 4 \\
\hline Sala Consilina (Salerno) & Middle Eneolithic & 2 \\
\hline Mirabella Eclano (Avellino) & Late Eneolithic & 2 \\
\hline Gricignano d'Aversa (Caserta) & Late Eneolithic & 1 \\
\hline Atena Lucana (Salerno) &
\end{tabular}



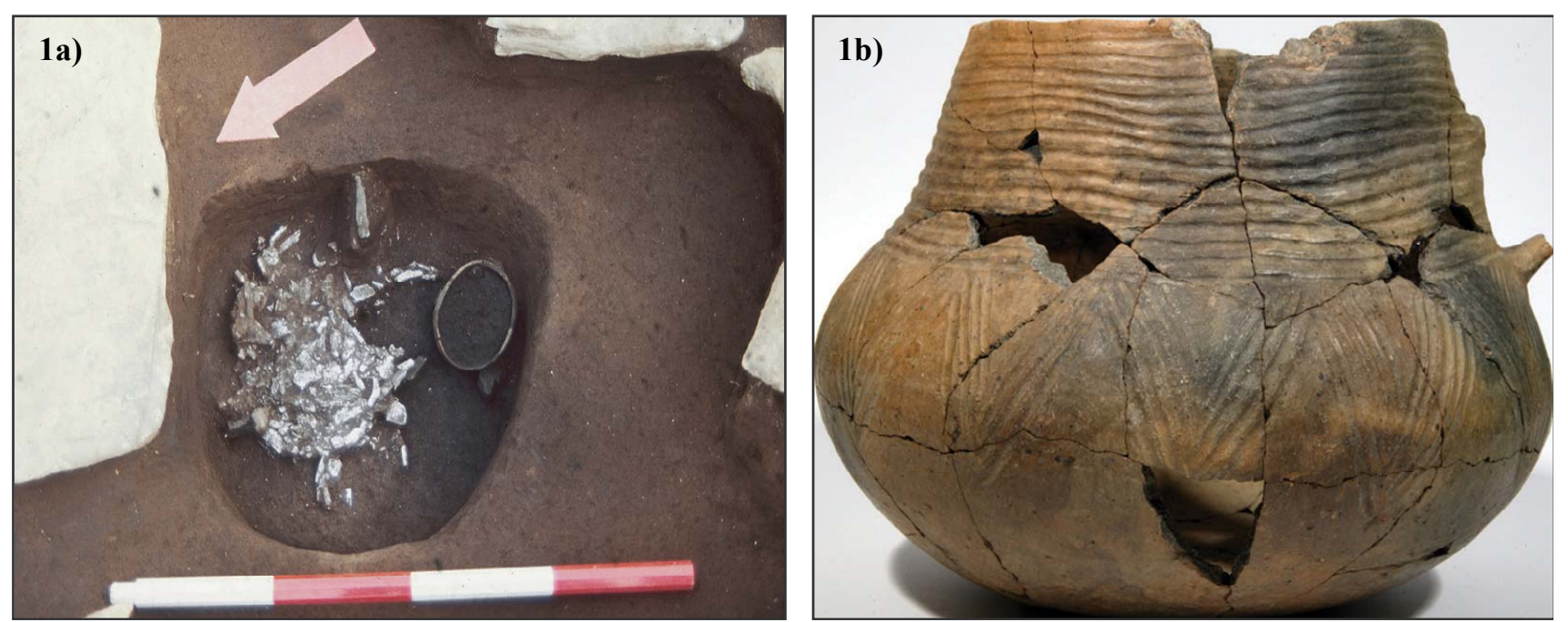

Fig. 1. a) Cremated bones with a cup and a copper dagger from a tomb in Structure 3. b) A jug from Structure 1.

Until now, the Taurasi tombs are the most ancient Italian cremations deposited in distinct tombs. In $\mathrm{S}$. Martino, the dead body together with grave-goods was cremated in a place different from the place of burial. Cremation remains were collected and directly deposited in the grave pits or vessels, which were put in the graves. For the first time, double burials occurred and one or more of the deceased were accompanied by specially cremated animals. The scarce copper finds - a dagger and a pin from the same tomb - indicate that in the time of Taurasi tombs metal was rare and highly valued (Talamo, 2004). All the structures and the tombs are referable to a distinctive archaeological phase of Eneolithic. For its distinctive characteristics, namely cremation ritual and the specific pottery (Fig. 1a-b), this culture was called "Taurasi". According to ${ }^{14} \mathrm{C}$ dating, Taurasi culture precedes the Gaudo and Laterza tombs (Talamo, 2004).

For ${ }^{14} \mathrm{C}$ dating were submitted charcoals from Tomb 3/1 (Structure 3) and Tomb 4/1 (Structure 4), which covered the graves, and from Tomb $2 / 9$ (Structure 2) and Tomb 5/4 (Structure 5), both probably from funerary pyres. The radiocarbon data are presented in Fig. 2.

When calibrated using vague priors (Buck et al., 1996), the majority of age ranges are distributed in the interval 3500-3300 cal BC. However, as a consequence of the characteristics of archaeological charcoal ${ }^{14} \mathrm{C}$ samples, the measured ${ }^{14} \mathrm{C}$ dates represent termini post quem and not termini ad quem for the investigated interments. The obtained age ranges give the time of growth of the dated tree rings and therefore a time lag is to be assumed between the obtained and the pursued dating information. Even if the time lag would be large (e.g. 200-300 calendar yrs), the Taurasi tombs would still clearly precede those of Gaudo and Laterza cultures. Given that we do not know from which part of log originated the charcoal samples measured, we chose to interpret these dates in a widest way.

- Santa Maria dei Bossi - Casalbore (Avellino)

In Santa Maria dei Bossi, a site few $\mathrm{km}$ from the modern village Casalbore, archaeological excavations in 1985 unearthed a sequence from Early Neolithic ("Ceramica Impressa" culture settlement) to the Roman times.
For our study, the Early Eneolithic cemetery consisting of several tombs is of importance.

The tombs, which may have contained inhumations and have yielded pottery and lithics (weaponry), represent a not clearly identifiable culture of the Early Eneolithic. Such archaeological classification corroborated the acquired ${ }^{14} \mathrm{C}$ evidence. The first ${ }^{14} \mathrm{C}$ date from this site measured in France on charcoal from one of the tombs yielded $4800 \pm 90$ BP (Albore Livadie and Gangemi, 1986; OxCal v3.10 and INTCAL04 give at $68.2 \%$ confidence level $3660-3510,3430-3380$ cal $\mathrm{BC}$, at $95.4 \%$ 3770-3360 cal BC).

In 2006, new ${ }^{14} \mathrm{C}$ dates on new samples from the Santa Maria dei Bossi - Casalbore tombs were measured in the CIRCE AMS laboratory in Caserta. The results are shown in Fig. 3, as ranges of calibrated ${ }^{14} \mathrm{C}$ ages, together with the only date in the literature. The ${ }^{14} \mathrm{C}$ age of the oldest samples are in agreement with the previous dating (4800 \pm 90 BP; Albore Livadie and Gangemi, 1986).

\section{Chronological investigations of Middle Eneolithic}

The Middle Eneolithic in Campania is characterized by the important Gaudo culture. This culture is known solely from the cemeteries, that complicates investigations of its absolute chronology. The tombs usually contain collective burials with inhumations buried in small chambers cut in soft rock (tuff or travertine), which were entered from an access well or shaft.

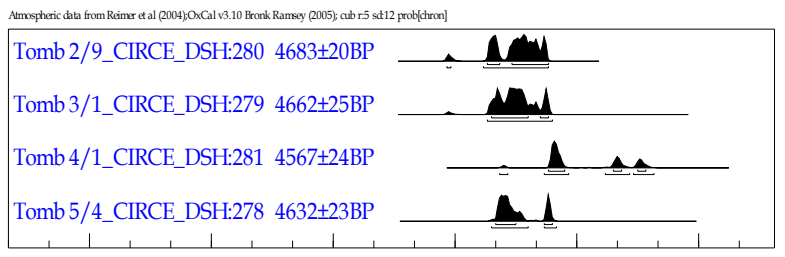

4500CalBC 4200CalBC 3900CalBC 3600CalBC 3300CalBC 3000CalBC

Calibrated date

Fig. 2. OxCal calibration of ${ }^{14} \mathrm{C}$ ages measured on 4 charcoal samples from tombs of the Taurasi site. 


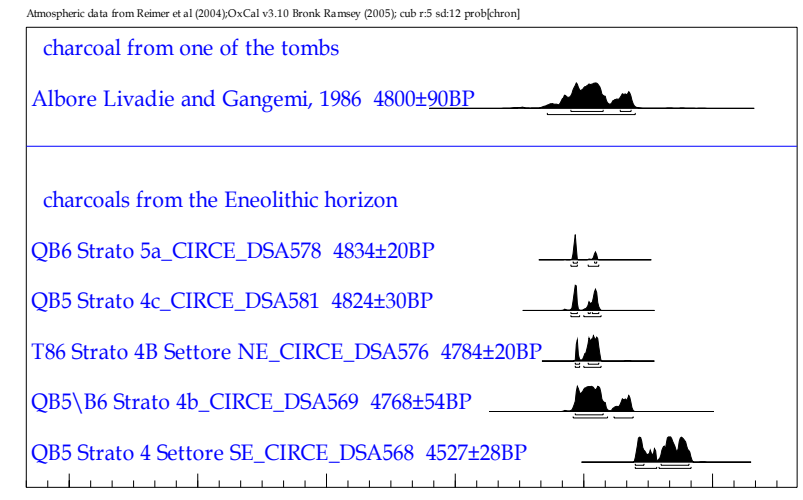

6000CalBC 5400CalBC 4800CalBC 4200CalBC 3600CalBC 3000CalBC

Calibrated date

Fig. 3. Calibration and comparison of results obtained in the present work for samples coming from S.Maria dei Bossi and the only date known in the literature.

However, excavations carried out over the past 20 years have exposed some settlements and cemeteries, which seem to be different from the sites of Gaudo culture as known by now. In order to investigate the absolute chronology of Middle Eneolithic, a settlement at Caivano (NA) and three cemeteries, namely Piano di Sorrento (NA), Sala Consilina (SA), and Mirabella Eclano (AV) have been investigated.

- La Trinità - Piano di Sorrento (Naples)

Building works in 1987 in La Trinità - Piano di Sorrento exposed five typical graves with a large amount of pottery. According to decorated pottery and typology of tombs, the burials belong to Gaudo culture. The relative chronology of the site (Albore Livadie, 1991) suggests that the graves 5,4 , and 3 belong to the ancient phase, grave 1 to the recent phase, and grave 2 to the intermediate phase. In 1993, pottery from two graves was dated by thermoluminescence (TL). The measurements, which gave for grave $12550 \pm 380 \mathrm{BC}$ and for grave 4 $2350 \pm 190 \mathrm{BC}$ (weighted average of three dates), were executed by The Physical Science Department of the University "Federico II" of Naples and CRIAA, Bordeaux, France (Vartanian et al., 2001).

In 2005, we obtained several bones from the Piano di Sorrento inhumations. Bones proved to be much degraded, with a very low content of or no collagen. Only two samples (from grave 2), chemically treated in the Research Laboratory for Archaeology and the History of Art of Oxford using collagen extraction protocol with an additional ultrafiltration step, yielded sufficient collagen for dating. However, from these two samples one was rejected because of its large standard error. In Fig. 4, we report the result for the remaining sample.

The above discussed ${ }^{14} \mathrm{C}$ dates of human bones and the TL dates of pottery from the literature represent the absolute chronological information about the Middle Eneolithic, particularly of Gaudo culture. Considering all dating results, it is DSH106 with its small error, what gives the best estimate of absolute date for the cemetery (2910-2870 cal BC; $55.2 \%$ on $68.2 \%$ probability; 29302850 cal BC; $63.7 \%$ on $95.4 \%$ probability; see Fig. 4) - TAV - IV sottotratta - Lotto 10 - Caivano (Naples)

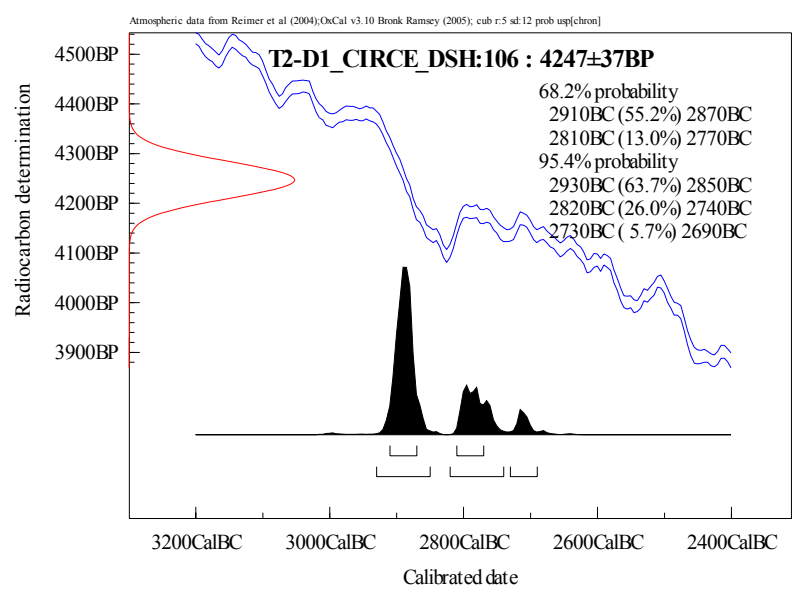

Fig. 4. Calibration of the radiocarbon age of a bone sample from pit grave 2 of Piano di Sorrento. Sample was chemically treated at Oxford laboratory and measured at CIRCE AMS system.

By now, Caivano is the first known Eneolithic village in Campania. The site discovered in 2005 was occupied over a large period in the Middle Eneolithic. However, assignment of the Caivano settlement to one of the regional Eneolithic cultures is complicated by the fact that until this discovery Campanian Eneolithic has been known solely from the cemeteries.

The first observations and studies of the pottery have shown that in the material culture from Caivano there are some analogies with Gaudo or maybe Taurasi cultures, and that it seems to precede Laterza culture. The Caivano settlement with its two phases is exceptional also from the point of volcanic chronostratigraphy. The first phase of this village is directly buried by the Agnano 3 Phlegrean eruption. The second one is included between Agnano 3 and Paleoastroni 2, both below Agnano Monte Spina eruption (4130 $\pm 50 \mathrm{BP}$, de Vita et al., 1999).

The absolute chronology of these eruptive depositions has not been conclusively solved, because only few indications, especially for Agnano 3, have been at hand. In fact, we only have a suggestion on its chronology from ${ }^{14} \mathrm{C}$ dates on charcoals coming from paleosol and thin humified layer, both underlying Monte St. Angelo Tephra (4440 \pm 50 BP; $4340 \pm 50$ BP, Di Vito et al., 1999), an eruption that happened after those of Cigliano and Pignatiello, all later than Agnano 3.

Accordingly, the Caivano settlement is important for absolute-chronological identification of these two eruptions (Agnano 3 and Paleoastroni 2) by means of radiocarbon dating of organic samples extracted from layers buried by the eruptions. In order to better determine the chronology of this site, charcoal and animal bone samples were collected from pits or hearths below the Agnano 3 eruption (i.e. Caivano settlement phase I) and within and above the Paleoastroni 2 eruption.

In Fig. 5, one can see the OxCal calibration of ${ }^{14} \mathrm{C}$ dates obtained in this work together with the results from the literature.

The DSH102 and DSH124 samples $(\mathbf{4 2 3 0} \pm \mathbf{2 0}$ BP, 4192 \pm 23 BP; $2900-2700$ cal BC, $68.2 \%$ probability; 2910-2670 cal BC, $95.4 \%$ probability) give a terminus post quem for Agnano 3, while Paleoastroni 2 is identi- 


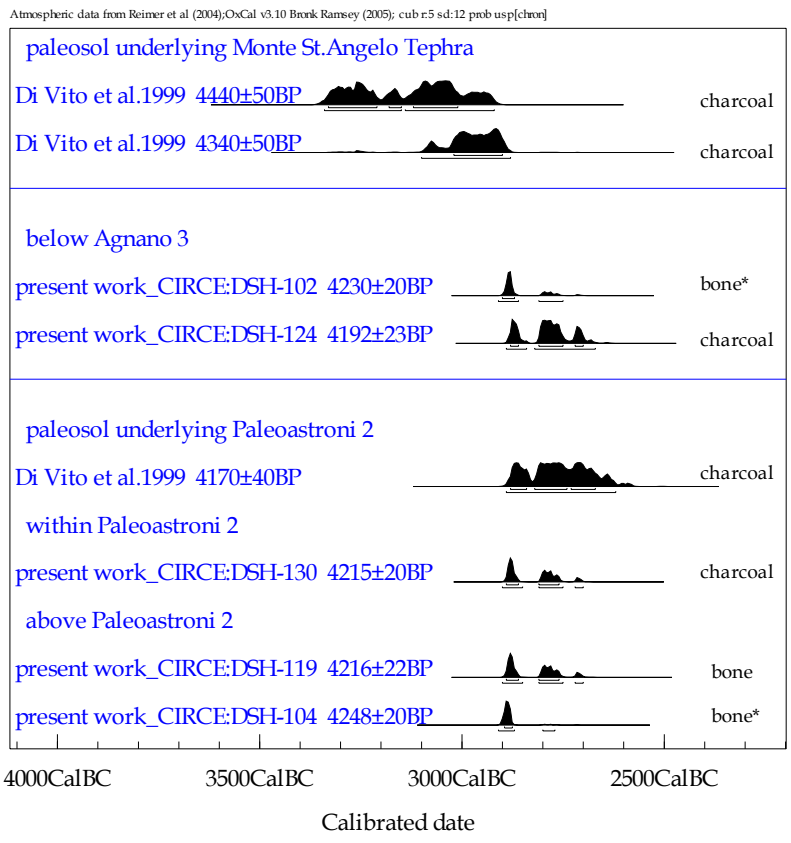

Fig. 5. Calibration and comparison of results obtained in the present work and other radiocarbon ages obtained in the literature. Our samples (CIRCE:DSH-102, 124, 130, 119, 104) were collected above Agnano 3 and within and above Paleoastroni 2. *Bone chemically treated at the Oxford laboratory.

fied by DSH130, DSH119, and DSH104 samples (4215 \pm 20 BP, 4216 \pm 22 BP, 4248 \pm 20 BP; $2895-2760$ cal BC, $68.2 \%$ probability; 2910-2700 cal BC, 95.4\% probability). Concerning Paleoastroni 2, the new dates are in agreement, within errors, with the date known until now. The radiocarbon dating of Agnano 3 is very close to $\mathrm{Pa}$ leoastroni 2. Both eruptions are placed at the beginning of the $3^{\text {rd }}$ millennium cal $\mathrm{BC}$, which is a period of intense and frequent activity of the Phlegrean Fields. It should be borne in mind that, in the Phlegrean stratigraphic area, three eruptions have been identified between Agnano 3 and Paleoastroni 2. To the already mentioned CiglianoPignatiello and Monte St. Angelo, Paleoastroni 1 (Di Vito et al., 1999) has to be added.

Analysis of the data has been made by the Bayesian tools of OxCal, namely as interval in the sequence of the two eruptions. The resulting overall agreement index $(40 \%)$ was below the suggested tenability level. This indicates that, within experimental errors, the interval is compatible with 0 .

To sum up the results of new ${ }^{14} \mathrm{C}$ chronology for Caivano, the Agnano 3 eruption, the re-settlement of the site and its destruction by Paleoastroni 2 are likely to have happened within a relatively short time-span almost certainly not exceeding 100 years.

\section{- Capo la Piazza - Sala Consilina (Salerno)}

Recent archaeological excavations at Sala Consilina have exposed a site with two different phases. The first phase is represented by structures with dry-stone walls and a small number of cremation tombs inside pots of Taurasi culture.

The second phase is a Middle Eneolithic cemetery with inhumation pit graves. As for artefacts, the inhuma- tion graves at Sala Consilina have yielded only pottery, which is not attributable to any archaeological culture known in Campanian Eneolithic. Apart from that, no other diagnostic elements appeared.

To investigate the second phase of this site (Sala Consilina II), bones coming from four inhumation pit graves were analysed. The radiocarbon ages obtained and calibrated by OxCal v3.10 are shown in Fig. 6.

Unlike Piano di Sorrento and Caivano, ranges of calibrated ${ }^{14} \mathrm{C}$ dates from the second phase of Sala Consilina reflect the plateau-like portion of the calibration curve in the first half of the $3^{\text {rd }}$ millennium cal BC. Accordingly, absolute dates for the Middle Eneolithic inhumations at Sala Consilina accompanied with the pottery are to be found somewhere between 2900 and 2500 cal BC.

- Madonna delle Grazie - Mirabella Eclano (Avellino)

The Madonna delle Grazie necropolis at Mirabella Eclano is the second most important necropolis of Gaudo culture after the eponymous site. The site was unearthed in the 1950s. Unfortunately, at present only few artefacts securely associated with archaeological contexts are known. The most important and best preserved tomb of the cemetery is the so-called Capo Tribù (chieftain) tomb. Here, a supine man was buried together with his dog and a rich assemblage of weapons, which indicate his importance. This tomb is a unique example within the whole evidence of Gaudo culture and therefore it was selected for ${ }^{14} \mathrm{C}$ dating.

The bones of deceased and bones of dog from the Capo Tribù tomb were analysed in 2008. The results in Fig. 7 show that both ${ }^{14} \mathrm{C}$ dates are calibrated against a plateaulike portion of the calibration curve between 2900 and $2500 \mathrm{cal} \mathrm{BC}$. These new absolute dates are further contribution to the debate about duration of Gaudo culture.

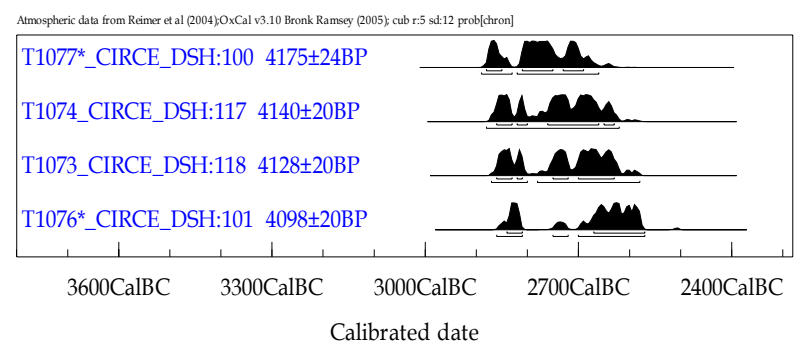

Fig. 6. OxCal calibration of bone samples coming from four pit graves of Sala Consilina. *Bone chemically treated at the Oxford laboratory.

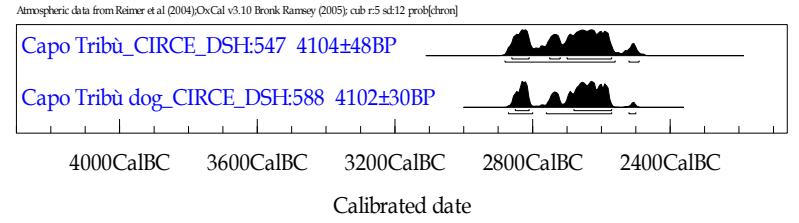

Fig. 7. OxCal calibration of two bone samples found in the Capo Tribú tomb at Mirabella Eclano (AV). The result corroborates the archaeological observation that both the human and the animal were buried together at the same time. 


\section{Chronological investigation of Late Eneolithic}

- US Navy "Forum” area - Gricignano d'Aversa (Caserta)

A large-scale excavation of a site in the area of US Navy logistic centre near Gricignano d'Aversa is one of those triggered by the recent large infrastructural projects in Campania.

In Gricignano, evidence of anthropic activity has been identified between the deposits of the Agnano-Monte Spina and Avellino Pumices. Meticulous investigation of so-called "Forum" area has exposed, between the deposits of Agnano-Monte Spina and Phlegrea 1, a large settlement with several apsed houses and two cemeteries with inhumations of a distinctive typology (Fugazzola Delpino et al., 2003). The settlement and the cemeteries, which might be of a just later date, are entirely referable to Laterza culture.

Prior to the discovery of Gricignano, typical materials of this culture were already known in Campania, as the Pontecagnano and the Castel Baronia sites (Gangemi, 1988; Talamo, 2006). However, the absolute chronology of Laterza culture has not been much clear.

Archaeological importance of the evidence from Gricignano resides in the fact that it illuminates transition between Late Eneolithic and the incipient Early Bronze Age represented by Palma Campania culture. Hence, research of interrelations between Laterza and Palma Campania cultures will contribute to the understanding of emergence of the Early Bronze Age in Campania.

Environmentally, the transition period is characterized by several eruptions of Somma-Vesuvius and Phlegrean Fields. Between the two big eruptions (Agnano-Monte Spina and Avellino Pumices) there were four Phlegrean Fields eruptions (Phlegrea 1, 2, 2 bis, 3). These were of small environmental impact, but in turn stimulated human habitation and triggered an intensive agrarian exploitation.

Accordingly, the ${ }^{14} \mathrm{C}$ dates from Gricignano provide also fresh data for the volcanic chronostratigraphy.

To investigate the absolute chronology of the "Forum" area at Gricignano, charred seeds from a storage pit cut into the paleosurface just on the top of the AgnanoMonte Spina level and sealed by the Phlegrea 1 eruption were collected. The results of DSH125_US2315-2254 and DSH126_US2315 samples are shown in Fig. 8, together with the only date present in the literature.

These new data give an upper limit for the chronology of Agnano MS and a lower limit for Phlegrea 1.

- Fosso Aimone - Atena Lucana (SA)

Recent archaeological excavations in Atena Lucana near Salerno uncovered an area of the craftsmanship production, referable to the transition period of Late Eneolithic - Early Bronze Age. Even if some cultural aspects are similar to Laterza, it is culturally almost pure context related to Çetina culture.

A charcoal coming from a hearth of this site supplied useful information about the Eneolithic - Bronze Age transition (see Fig. 9). Radiocarbon age of sample, with calendar age interval of $2470-2270$ cal BC $(60.1 \%$, on $68.2 \%$ probability), dates the site to the second half of the $3^{\text {rd }}$ millennium BC.

\section{SUMMARY AND CONCLUSIONS}

The presented 24 newly measured ${ }^{14} \mathrm{C}$ dates from eight sites provide the largest published radiocarbon data set for Campanian Eneolithic. Covering the entire period, they have enabled comprehensive and conclusive investigations not only into well-known cultures. The new data have also strongly contributed to the recognition of unknown cultural phenomena and to the absolute dating of volcanic activity in the region. Table 2 shows details of all samples presented in the study, including sample code, ${ }^{14} \mathrm{C}$ age with 1 standard deviation, calibrated ages for $1 \sigma$ and $2 \sigma$ ranges, sample material, site, and archaeological classification of sampled context.

As for early Eneolithic in Campania, evidence from two sites has been explored. First, it is a new cultural phenomenon called "Taurasi" identified by its characteristic findings. Four ${ }^{14} \mathrm{C}$ dates on charcoals from Taurasi (AV) show that the site was occupied from early second half of the $4^{\text {th }}$ millennium cal BC. The tombs sampled for charcoals contained also cremated bones, which may well serve to refine the absolute dating in the future. At the same time, they enable to make a comparison of ${ }^{14} \mathrm{C}$ dates measured on different material from the same site.

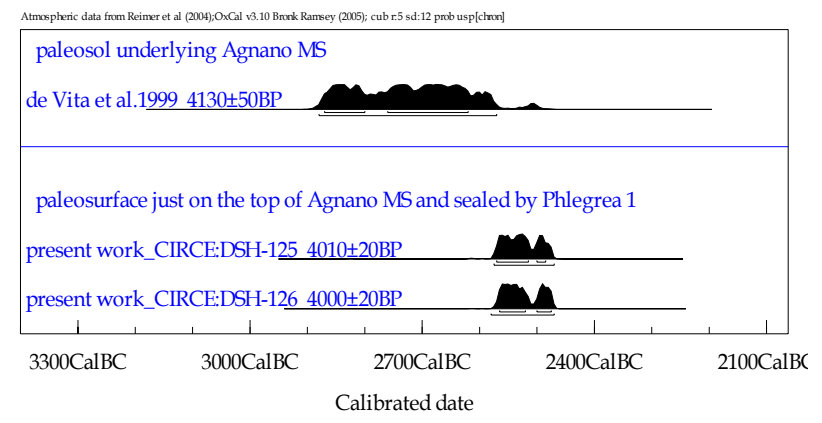

Fig. 8. Calibration and comparison of results obtained in the present work for charred seeds coming from "Forum" area - Gricignano d'Aversa (CE) and the only ${ }^{14} \mathrm{C}$ age obtained in the literature, for the Agnano MS eruption.

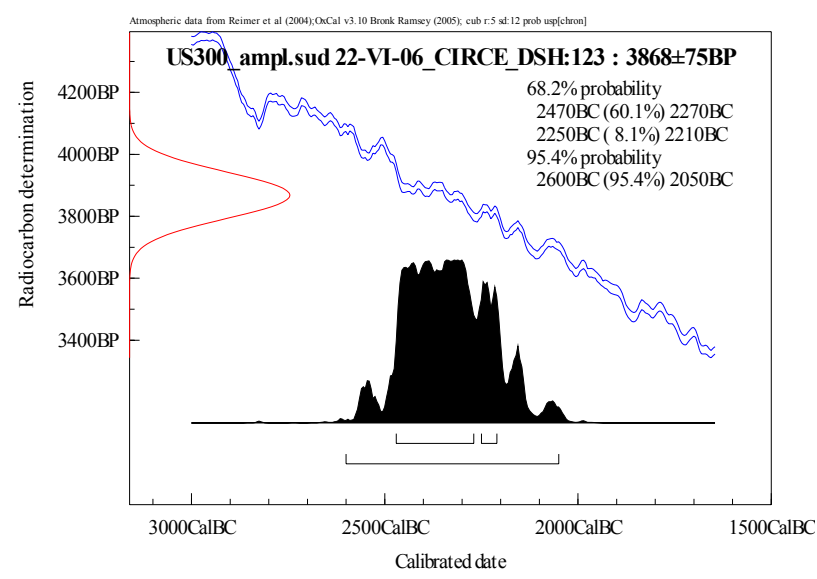

Fig. 9. Calibration of the radiocarbon age of a charcoal coming from Atena Lucana (SA). 
I. Passariello et al.

Table 2. All results obtained in this work from samples collected in sites belonging to the Eneolithic period are shown with own sample code, ${ }^{14} \mathrm{C}$ age with 1 standard deviation, calibrated ages for $1 \sigma$ and $2 \sigma$ ranges, type of material, site, and archaeological classification of sampled context.

\begin{tabular}{|c|c|c|c|c|c|c|}
\hline Sample Code & Locality & $\begin{array}{l}\text { Archaeological } \\
\text { period/Culture }\end{array}$ & Sample description & $\begin{array}{l}{ }^{14} \mathrm{C} \text { age } \\
\pm 1 \sigma\end{array}$ & $\begin{array}{c}\text { Calibrated } \\
\text { age } \\
\text { (BC, } 68.2 \%)\end{array}$ & $\begin{array}{c}\text { Calibrated } \\
\text { age } \\
\text { (BC, } 95.4 \%)\end{array}$ \\
\hline CIRCE_DSH:280 & Taurasi (AV) & $\begin{array}{l}\text { Early Eneo- } \\
\text { lithic/Taurasi }\end{array}$ & charcoal_Tomb 2/9 from structure 2 & $4683 \pm 20$ & $3520-3370$ & $3620-3370$ \\
\hline CIRCE_DSH:279 & Taurasi (AV) & $\begin{array}{l}\text { Early Eneoli- } \\
\text { thic/Taurasi }\end{array}$ & charcoal_Tomb 3/1 from structure 3 & $4662 \pm 25$ & $3510-3370$ & $3520-3360$ \\
\hline CIRCE_DSH:281 & Taurasi (AV) & $\begin{array}{l}\text { Early Eneoli- } \\
\text { thic/Taurasi }\end{array}$ & charcoal_Tomb 1/4 from structure 4 & $4567 \pm 24$ & $3370-3130$ & $3490-3110$ \\
\hline CIRCE_DSH:278 & Taurasi (AV) & $\begin{array}{l}\text { Early Eneoli- } \\
\text { thic/Taurasi }\end{array}$ & charcoal_Tomb 5/4 from structure 5 & $4632 \pm 23$ & $3500-3360$ & $3510-3350$ \\
\hline CIRCE_DSA:578 & $\begin{array}{l}\text { Casalbore } \\
\text { (AV) }\end{array}$ & Early Eneolithic & charcoal_QB6 Strato 5a & $4834 \pm 20$ & $3650-3540$ & $3660-3530$ \\
\hline CIRCE_DSA:581 & $\begin{array}{c}\text { Casalbore } \\
(\mathrm{AV})\end{array}$ & Early Eneolithic & charcoal_QB5 Strato 4c & $4824 \pm 30$ & $3660-3530$ & $3660-3520$ \\
\hline CIRCE_DSA:576 & $\begin{array}{l}\text { Casalbore } \\
\text { (AV) }\end{array}$ & Early Eneolithic & charcoal_T.86 Strato 4B Settore NE & $4784 \pm 20$ & $3640-3530$ & $3640-3520$ \\
\hline CIRCE_DSA:569 & $\begin{array}{l}\text { Casalbore } \\
\text { (AV) }\end{array}$ & Early Eneolithic & charcoal_QB5/B6 Strato 4b & $4768 \pm 54$ & $3640-3510$ & $3650-3370$ \\
\hline CIRCE_DSA:568 & $\begin{array}{c}\text { Casalbore } \\
(\mathrm{AV})\end{array}$ & Early Eneolithic & charcoal_QB5 Strato 4 Settore SE & $4527 \pm 28$ & $3360-3110$ & $3360-3100$ \\
\hline CIRCE_DSH:106 & $\begin{array}{c}\text { Piano di } \\
\text { Sorrento (NA) }\end{array}$ & $\begin{array}{l}\text { Middle Eneolithic } \\
\text { /Gaudo }\end{array}$ & human bone*_T2-D1 & $4247 \pm 37$ & $2910-2270$ & $2930-2690$ \\
\hline CICRE_DSH:102 & Caivano (NA) & Middle Eneolithic & S.489/492_US67_bone*__below Agnano 3 & $4230 \pm 20$ & $2900-2870$ & $2910-2750$ \\
\hline CIRCE_DSH:124 & Caivano (NA) & Middle Eneolithic & S.489/492_US67_charcoal_below Agnano 3 & $4192 \pm 23$ & $2880-2700$ & $2890-2670$ \\
\hline CIRCE_DSH:130 & Caivano (NA) & Middle Eneolithic & $\begin{array}{c}\text { S.489/492_US66_charcoal_within Pa- } \\
\text { leoastroni } 2\end{array}$ & $4215 \pm 20$ & $2890-2760$ & $2900-2700$ \\
\hline CIRCE_DSH:119 & Caivano (NA) & Middle Eneolithic & S.489/492_US89_bone_above Paleoastroni 2 & $4216 \pm 22$ & $2890-2760$ & $2900-2700$ \\
\hline CIRCE_DSH:104 & Caivano (NA) & Middle Eneolithic & S.489/492_US90_bone*_above Paleoastoni 2 & $4248 \pm 20$ & $2895-2875$ & $2910-2770$ \\
\hline CIRCE_DSH:101 & $\begin{array}{l}\text { Sala Consili- } \\
\text { na (SA) }\end{array}$ & Middle Eneolithic & human bone_T.1076* & $4098 \pm 20$ & $2840-2570$ & $2860-2570$ \\
\hline CIRCE_DSH:100 & $\begin{array}{l}\text { Sala Consili- } \\
\text { na (SA) }\end{array}$ & Middle Eneolithic & human bone_T.1077* & $4175 \pm 24$ & $2880-2690$ & $2890-2660$ \\
\hline CIRCE_DSH:118 & $\begin{array}{l}\text { Sala Consili- } \\
\text { na (SA) }\end{array}$ & Middle Eneolithic & human bone_T.1073 & $4128 \pm 20$ & $2860-2630$ & $2870-2580$ \\
\hline CIRCE_DSH:117 & $\begin{array}{l}\text { Sala Consili- } \\
\text { na (SA) }\end{array}$ & Middle Eneolithic & human bone_T.1074 & $4140 \pm 20$ & $2860-2630$ & $2880-2620$ \\
\hline CIRCE_DSH:547 & $\begin{array}{c}\text { Mirabella } \\
\text { Eclano (AV) }\end{array}$ & $\begin{array}{l}\text { Middle Eneolithic } \\
\text { /Gaudo }\end{array}$ & human bone_Capo Tribù & $4104 \pm 48$ & $2860-2570$ & $2880-2490$ \\
\hline CIRCE_DSH:588 & $\begin{array}{c}\text { Mirabella } \\
\text { Eclano (AV) }\end{array}$ & $\begin{array}{l}\text { Middle Eneolithic } \\
\text { /Gaudo }\end{array}$ & dog_Capo Tribù & $4102 \pm 30$ & $2850-2750$ & $2870-2500$ \\
\hline CIRCE_DSH:125 & $\begin{array}{l}\text { Gricignano } \\
\text { d'Aversa (CE) }\end{array}$ & $\begin{array}{l}\text { Late Eneoli- } \\
\text { thic/Laterza }\end{array}$ & $\begin{array}{c}\text { US2315-2254_charred seed_paleosurface on } \\
\text { the top of Agnano MS and sealed by Phlae- } \\
\text { grea } 1\end{array}$ & $4010 \pm 20$ & $2570-2485$ & $2575-2470$ \\
\hline CIRCE_DSH:126 & $\begin{array}{l}\text { Gricignano } \\
\text { d'Aversa (CE) }\end{array}$ & $\begin{array}{l}\text { Late Eneoli- } \\
\text { thic/Laterza }\end{array}$ & $\begin{array}{l}\text { US2315_charred seed_paleosurface on the } \\
\text { top of Agnano MS and sealed by Phlaegrea } 1\end{array}$ & $4000 \pm 20$ & $2565-2475$ & $2580-2470$ \\
\hline CIRCE_DSH:123 & $\begin{array}{l}\text { Atena Lucana } \\
\text { (SA) }\end{array}$ & $\begin{array}{l}\text { Late Eneoli- } \\
\text { thic/Cetina }\end{array}$ & charcoal_US 300 ampl. Sud 22-IV-06 & $3868 \pm 75$ & $2470-2210$ & $2600-2050$ \\
\hline
\end{tabular}

* Bone chemically treated at the Oxford laboratory.

Second, five new ${ }^{14} \mathrm{C}$ dates on samples from Santa Maria dei Bossi (Casalbore, AV) place the Eneolithic phase of this site just before the time of Taurasi. However, according to recent investigations of archaeological evidence, both sites seem to represent the same and by now unknown cultural phenomenon.

Accordingly, Taurasi and S. Maria dei Bossi represent a sizeable part of $4^{\text {th }}$ millennium cal BC. It is of interest that similar pottery and cremations have been recently found in the first phase of Sala Consilina. Results from this site that is still under investigation are awaited to enumerate chronological evidence for the Early Eneolithic in Campania.

Next, Campanian Middle Eneolithic evidence has been investigated. We have studied Piano di Sorrento and Mirabella Eclano, two sites of Gaudo culture, and two further sites, which by now remain culturally closely undetermined - Sala Consilina II and Caivano. Twelve ${ }^{14} \mathrm{C}$ dates have shown that these four sites date from the first half of $3^{\text {rd }}$ millennium cal BC. Such result implies that the Middle Eneolithic in Campania was a period, when several cultures coexisted or in short intervals fol- 
lowed one after another. As outlook, it is new Campanian sites, presently under excavations, what in the future may give important insights into the chronology of Gaudo culture.

Our study has made also a contribution to absolute dating of volcanic eruptions by means of samples from Caivano, located below Agnano 3 and above Paleoastroni 2 deposits. The new data represent a chronostratigraphic marker for cultural and paleoenvironmental reconstructions and may well be useful for future research.

The Late Eneolithic in Campania characterize three ${ }^{14} \mathrm{C}$ dates from Gricignano d'Aversa and Atena Lucana (2570-2210 BC, 68.2\% probability; 2575-2050 cal BC, 95.4\% probability). Moreover, Gricignano d'Aversa gives new indications about chronology of AgnanoMonte Spina and Phlegrea 1 eruptions.

Another important result concerns the distinction between two cultural phases during the second half of the $3^{\text {rd }}$ millennium cal BC, namely Laterza, well known in Campania, and Çetina, identified in this region for the first time. Further investigations and analyses on bones coming from Gricignano d'Aversa and Torre le Nocelle (AV) will allow us to seek the start of Laterza culture deeper in the past.

Ultimately, the new measurements of CIRCE AMS laboratory in Caserta enabled to construct the absolute chronology of Eneolithic in Campania from its beginnings in the early second half of the $4^{\text {th }}$ millennium until its end in the late $3^{\text {rd }}$ millennium cal BC. The fresh absolute-chronological evidence has shed new light on cultural development of Campanian Eneolithic and has shown that the beginning of the period that was thought to have been well established has to be re-evaluated.

Last but not least, the work has produced new evidence relevant for the regional volcanic chronostratigraphy and for understanding the relationship between human habitation and volcanic activity in the region.

\section{ACKNOWLEDGEMENTS}

We would to thank the Research Laboratory for Archaeology and the History of Art at Oxford and in particular Dr. Fiona Brock, Dr. Tom Higham and Prof. Christopher Bronk Ramsey for the hospitality in their laboratory and help in the chemical preparation of five bone samples.

The archaeologist Claude Albore Livadie; the Soprintendenza per i Beni Archeologici di Napoli e Pompei; Dr. Elena La Forgia and Dr. Antonio Salerno of the Soprintendenza per i Beni Archeologici di Caserta e Benevento; Dr. Anna Di Santo and Dr. Adele Lagi of the Soprintendenza per i Beni Archeologici di Salerno e Avellino, granting access to the samples analyzed in this work, are gratefully acknowledged.

\section{REFERENCES}

Albore Livadie C, 1991. La Preistoria e la Protostoria (The Prehistory and the Protohistory). Napoli, Storia del Mezzogiorno 1(1): 59-118 (in Italian).

Albore Livadie C and Gangemi G, 1986. Casalbore (Avellino). Rivista di Scienze Preistoriche notiziario XI (1-2): 414 (in Italian).
Albore Livadie C and Gangemi G, 1988. Sepolture eneolitiche da Casalbore, loc. S. Maria dei Bossi (Avellino) (Eneolithic tombs from the S.Maria dei Bossi locality (Casalbore, Avellino)). In: L'età del Rame in Europa, Viareggio 15/18 ottobre 1987, "Rassegna di Archeologia" VII: 572-573 (in Italian).

Arslanov KhA and Svezhentsev YuS, 1993. An improved method for radiocarbon dating fossil bones. Radiocarbon 35(3): 387-391.

Bailo Modesti G and Salerno A, 1998. Pontecagnano. II.5 La necropoli eneolitica - L'età del Rame in Campania nei villaggi dei morti (Pontecagnano. II.5 The Eneolithic necropolis - The Copper age in Campania in the villages of the dead). QUADAARC 11 (in Italian).

Brown TA, Nelson DE, Vogel JS and Southon JR, 1988. Improved collagen extraction method by modified Longin method. Radiocarbon 30(2): 171-177.

Bronk Ramsey C, 2001. Development of the radiocarbon program OxCal. Radiocarbon 43(2A): 355-63.

Bronk Ramsey C, 2005. Improving the resolution of radiocarbon dating by statistical analysis. In: Levy TE and Higham TFG, eds., The Bible and Radiocarbon Dating: Archaeology, Text and Science. London, Equinox: 57-64.

Bronk Ramsey C, Higham T, Bowles A and Hedges R, 2004. Improvements to the pre-treatment of bone at Oxford. Radiocarbon 46(1): 155-163.

Buck CE, Cavanagh WG and Litton CD, 1996. The Bayesian Approach to Interpreting Archaeological Data. Chichester, Wiley: 226-232

de Vita S, Orsi G, Civetta L, Carandente A, D’Antonio M, Deino A, di Cesare T, Di Vito MA, Fisher RV, Isaia R, Marotta E, Necco A, Ort M, Pappalardo L, Piochi M and Southon J, 1999. The AgnanoMonte Spina eruption (4100 years BP) in the restless Campi Flegrei caldera (Italy). Journal of Volcanology and Geothermal Research 91: 269-301, DOI:10.1016/S0377-0273(99)00039-6.

Di Vito MA, Isaia R, Orsi G, Southon J, de Vita S, D’Antonio M, Pappalardo L and Piochi M, 1999. Volcanism and deformation since 12,000 years at the Campi Flegrei caldera (Italy). Journal of Volcanology and Geothermal Research 91: 221-246, DOI:10.1016/S0377-0273(99)00037-2.

Fugazzola Delpino MA, Salerno A, Tagliacozzo A, Tinè V and Vanzetti A, 2003. Una comunità della facies di Laterza nella pianura campana: 1'area "Forum" di Gricignano-US NAVY (CE) (A community of the Laterza culture in the Campania plain: the "Forum" area at Gricignano-US NAVY (CE)). Atti della XXXV Riunione Scientifica. Le comunità della preistoria italiana. Studi e ricerche sul Neolitico e le età dei metalli. Castello di Lipari, 2-7 Giugno 2000. Firenze 2003: 199-214 (in Italian).

Gangemi G, 1988. Un insediamento di tipo Laterza a Castel Baronia (Avellino) (A settlement of the Laterza culture at Castel Baronia (Avellino)). In: L'età del Rame in Europa, Viareggio 15/18 ottobre 1987, "Rassegna di Archeologia" VII: 570-571 (in Italian).

Holloway RR, 1973. Buccino. The eneolithic necropolis of S. Antonio and other prehistoric discoveries made in 1968 and 1969 by Brown University, Roma.

Longin R, 1971. New method of collagen extraction for radiocarbon dating. Nature 230: 241-242, DOI:10.1038/230241a0.

Marzaioli F, Borriello G, Passariello I, Lubritto C, De Cesare N, D'Onofrio A and Terrasi F, 2008. Zinc reduction as an alternative method for AMS radiocarbon dating: process optimization at CIRCE. Radiocarbon 50(1): 139-149.

Mook WG and Streurman HJ, 1983. Physical and chemical aspects of radiocarbon dating. In: Mook WG and Waterbolk HTJ, eds., Proc. Groningen Symp. ${ }^{14} \mathrm{C}$ and Archaeology. PACT 8-II.1: 31-53.

Passariello I, Albore Livadie C, Talamo P, D’Onofrio A, Lubritto C, Terrasi F, 2009. ${ }^{14} \mathrm{C}$ chronology of "Avellino Pumices" eruption and timing of human re-occupation of the devasted region. Radiocarbon 51(2): 803-816.

Passariello I, Marzaioli F, Lubritto C, Rubino M, D’Onofrio A, De Cesare N, Borriello G, Casa G, Palmieri A, Rogalla D, Sabbarese $\mathrm{C}$ and Terrasi F, 2007. Radiocarbon sample preparation at the CIRCE AMS laboratory in Caserta, Italy. Radiocarbon 49(2): 225-232.

Piotrowska N and Goslar T, 2002. Preparation of bone samples in the Gliwice Radiocarbon Laboratory for AMS radiocarbon dating. Isotopes Environ Health Stud 38(4): 267-275, DOI 10.1080/10256010208033272.

Reimer PJ, Baillie MGL, Bard E, Bayliss A, Warren BJ, Bertrand CJH, Blackwell PG, Buck CE, Burr GS, Cutler KB, Damon PE, Lawrence ER, Fairbanks RG, Friedrich M, Guilderson TP, Hogg AG, 
Hughen KA, Kromer B, McCormac G, Manning S, Bronk Ramsey C, Reimer RW, Remmele S, Southon JR, Stuiver M, Talamo S, Taylor FW, van der Plicht J and Weyhenmeyer EC, 2004. Intcal04 terrestrial radiocarbon age calibration, 0-26 cal kyr BP. Radiocarbon 46(3): 1029-1058.

Stafford TW, Hull AJT, Brendell K, Duhamel RC and Donahue D, 1987. Study of bone radiocarbon dating at the University of Arizona NSF Accelerator facility for radioisotope analysis. Radiocarbon 29(1): 24-44

Talamo P, 2004. La contrada di San Martino di Taurasi: il sito e il suo territorio (The S. Martino district at Taurasi: the site and its territory). In: Taurasi, un nuovo aspetto dell'Eneolitico in Campania, Guida alla mostra, Salerno 2004: 1-35 (in Italian).

Talamo P, 2006. L'aspetto campano di Laterza in Irpinia (The Campanian aspect of Laterza in Irpinia) XXVI Convegno sulla Preistoria - Protostoria e Storia della Daunia. San Severo 2005: 83-96 (in Italian).

Talamo P, 2008a. Dinamiche culturali nelle aree interne della Campania centro-settentrionale durante le prime fasi dell'Eneolitico (Cultural dynamics in the internal areas of north-central Campania during the first stages of Eneolithic). RSP LVIII: 125-164 (in Italian).

Talamo P, 2008b. Le aree interne della Campania centro-settentrionale durante le fasi evolute dell'Eneolitico: osservazioni sulle dinamiche culturali (The internal areas of north-central Campania during the advanced stages of Eneolithic: observations on the cultural dynamics) Origini $X X X$, N.S. IV: 187-220 (in Italian).

Terrasi F, Rogalla D, De Cesare N, D'Onofrio A, Lubritto C, Marzaioli F, Passariello I,. Rubino M, Sabbarese C, Casa G, Palmieri A, Gialanella L, Imbriani G, Roca V, Romano M, Sundquist M and Loger R, 2007. A new AMS facility in Caserta/Italy. Nuclear Instrument and Methods in Physics Research Section B 259: 14-17, DOI:10.1016/j.nimb.2007.01.139.

Terrasi F, De Cesare N, D’Onofrio A, Lubritto C, Marzaioli F, Passariello I, Rogalla D, Sabbarese C, Borriello G, Casa C and Palmieri A, 2008. High precision ${ }^{14} \mathrm{C}$ AMS at CIRCE. Nuclear Instruments and Methods in Physics Research Section B 266: 22212224, DOI 10.1016/j.nimb.2008.02.079.

Vartanian E, Guibert P, Bechtel F, Schvoerer M and Albore Livadie C, 2001. Contribution de la thermoluminescence à la chronologie de la culture du Gaudo: datation de cèramiques du site de La Trinità, Piano di Sorrento, Italie (The contribution of the thermoluminiscence to the chronology of the Gaudo culture: dating of pottery from the La Trinità site, Piano di Sorrento, Italy). L'Anthropologie 105: 421-434. DOI: 10.1016/S0003-5521(01)80024-8 (in French). 